\title{
A Learning System Design Based on Digital Technology Utilization
}

\author{
Lianly Rompis \\ lrompis@unikadelasalle.ac.id \\ Universitas Katolik De La Salle Manado
}

\begin{abstract}
Digital technology in Indonesia, especially in Manado, begin to grow very rapidly followed by the availability of adequate technology market, better financial economy, and high enthusiasm from the local people, mostly academic educators. Supported by the existence of network based technology, it is mostly expected that the process of transferring information and learning in classroom will be easier and no longer become great problem in the future. People will acceptdigital technology not as a threat, but cultivate and utilize them for the improvement of human civilization, while keep maintaining respect to traditional learning and manual opinions and analysis because after all those concepts are merely the best. This paper based on author experience, observations, and reviews, offers solutions to utilize digital technology for developing aneffective learning process. The research methods are literature study, analysis taken from personal experience, system design, and future implementation. The results of this research givesperspective to design a learning system in a proper way, using digital technology individually or integrated, which will also support research activities and improve good digital technology products designed and produced by people of Indonesia and other Nations.
\end{abstract}

Keywords-learning system, digital technology, information application, innovation tool, learning media

\section{INTRODUCTION}

\subsection{Background}

The development of digital technology in Indonesia in two last decades is very fast, spread evenly to every city, including Manado which located in the north of Sulawesi.This technology growth is vastly driven by the availability of many sorts of good performance technology comes from various nations, with unique models that so innovative for people to use. It is also supported by the society's high financial economy, and high enthusiasm from communities, mostly academic educators that need information for teaching and educating students.

We should agree that the basic concept of digital technology which comes from analog nature is an amazing invention from our past and will valuable for generations. With binary based system, electronics and network technology, it is expected that the process of transferring information and classroom learning will be easier, more flexible, and do not bring a great problem forhuman future activities. A digital technology should not be seen as a threat, but as a meaningful thing, where we can utilize them for the improvement of human civilization, and keep maintaining respect to traditional learning and manual opinions or analysis because they are still the best of all. A learning system based on digital technology utilization for information and innovation should be well designed to achieve the education gold. However, the security of technology should still be considered to maintain the dignity and sustainability of human civilization. 


\subsection{Previous Study}

Previously a research study has been done in Electrical Engineering Study Program at Universitas Katolik De La Salle Manado to find out whether Media Audio Video can be utilized as one of the supporting facilities in the teaching and learning process. Both lecturers and students need a learning process. The development of science and technology will indirectly require them continually to think and learn. Although the teachinglearning process in general has been running well but still needs to be supported by good learning media so that it can be in line with the vision and mission of the university and able to make the Faculty of Engineering as a front liner in the field of Information Technology. [3,4,5]

\section{LITERATUR REVIEW}

\subsection{Facts About Digital Technology}

The development of digital technology needs to be utilized together in a positive way to support the development of a nation.Progressing technology certainly opens up new opportunities and it can encourage change and bring positive social impacts in a community.

To encourage the use of information technology that can support various formal and informal activities at college or university level, Telkomsel will hold a Digital Community Campus program that planned to be implemented in 20 campuses in 20 cities in Indonesia. On the other hand, Telkomsel encourages program \#InternetBAIK (Responsible Safe Inspirational and Creative), where the main participants come from school will be equipped with knowledge and understanding to use the Internet and information technology positively. [10] Telkomsel's subscribers in Manado and its surrounding areas are becoming increasingly using data. $80 \%$ of Telkomsel's customers in Manado have switched to broadband services.[11]

Central Bureau of Statisticsnoted, the growth rate of internet users in eastern Indonesia reached the highest level compared to other regions in Indonesia.The data is contained by BPS survey results in collaboration with the Indonesian Internet Service Provider Association.Head of BPS revealed for interprovince industry, North Sulawesi recorded as the province that has 100 percent or the highest ranking that uses computers and internet in business activities.While the second rank is West Kalimantan 94.12 percent above the Province of DKI Jakarta as the center of government which reached 90.83 percent. [9]

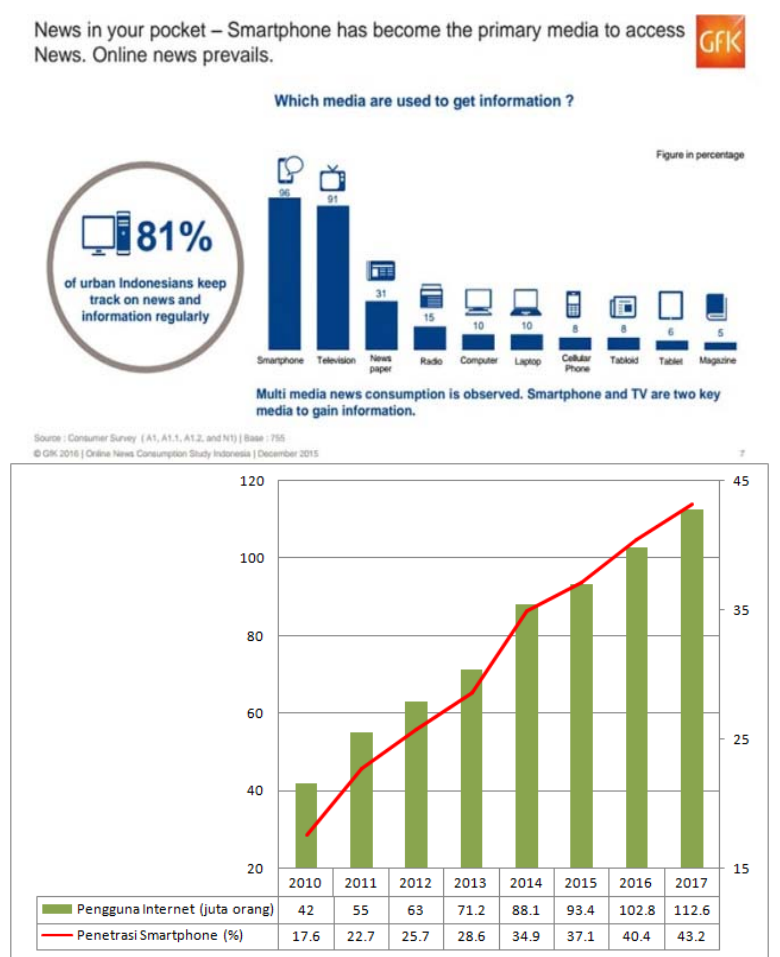

Figure 1.Internet and Smartphone Users Statistics (E-marketer dan Asosiasi Penyelenggara Jasa Internet Indonesia, 2017)

\subsection{Broadband Evolution}

Through the use of computers and telecommunications networks, humans have been able to extend their power of thinking, influence, and productivity, just as those in the industrial age were able to extend the power of physical through the heavy machinery. Exciting developments continue unbated in many areas that are key to the ongoing evolution of broadband devices, applications, and network infrastructures. 
These remarkable developments are propelling the broadband evolution, creating good reasons to pursue next-generation networks in digital world. [1,2]

\subsection{Adult Education and Learning Process}

Education for adults has different approaches scopes, goals, and strategies compared to education for children. It focuses on lifelong learning to learn the skills gained in self-directed. In conducting their educational process, adults prefer to study in free conditions, do not like rote, prefer to solve problems and practical matters. They also use different types of books, print media (e.g. books, modules, booklets, leaflets, charts, photos, newspapers, magazines) and non-print media (e.g. radio cassette, power point slides, videos).

Lecturers are people who play a very important role in organizing a learning process in classroom. The classroom consists of a number of students who are mentored by teachers to explore the world and learn how to direct the exploration results to be useful.

The success of student learning is strongly influenced by the way a teacher manages the learning process. Information-processing learning models basically focus on ways to strengthen the internal impulses (coming from within) the human himself to understand other humans by exploring and organizing data sensing problems and working their way through solutions and developing language to express them.

Generally, many information processing models can be applied to learning goals of different ages. Included in this group is the model of Concept Achievement, Inductive thinking, Exercise Research, Initial Guide, Memorization, Intellectual Development, and Scientific Research. [6,7]

\section{RESEARCH METHODOLOGY}

This research was conducted with qualitative approaches. Data was taken from previous research, observations, personal experience, and survey. Analysis is done using tables and interpretations, with the help of system design concept and current digital technology. The methods being used are literature study, analysis from personal experience, system design, and future implementation.

\subsection{Literature Study}

Collecting sources of information, observations, and references related to digital technology trends and development was the first step of this research. Several media have been used as reference, such as books, journals, and online articles.

\subsection{Personal Experience}

Before started a literature study, I already have some personal experiences in teaching classrooms with different subjects focusing on engineering field, mainly in electrical engineering. Literature study helped me to conduct analysis from these experiences.

\subsection{System Design}

Taken the important and main points of analysis, I tried to derive a design of a learning system based on digital technology utilization for information and innovation.

\subsection{Future Implementation}

From the learning system design concept, the output of research derived ideas and suggestions for future implementation in facing the development of digital technology and education future programs.

\section{RESULTS AND DISCUSSION 4.1 Analysis from Personal Experiences}

From author's personal experiences in teaching several classrooms with different subjects focusing mainly in electrical engineering field, a list of positive outcomes has been made for self-evaluation: 
Table 1.Positive Outcomes from Personal Experiences: How do academic educators and students respond?

\begin{tabular}{|c|l|}
\hline NO & $\begin{array}{c}\text { HOW DO ACADEMIC EDUCATORS } \\
\text { AND STUDENTS RESPOND? }\end{array}$ \\
\hline 1 & Prefer interactive learning \\
\hline 2 & Prefer to learn by given problem examples \\
\hline 3 & Like listening audios and watching videos \\
\hline 4 & More enthusiastic with practical activities \\
\hline 5 & Interested in doing visit study \\
\hline 6 & Need flexible time \\
\hline 7 & $\begin{array}{l}\text { Open to the development of digital } \\
\text { technology }\end{array}$ \\
\hline
\end{tabular}

Table 2.Positive Outcomes from Personal Experiences: What do educators and students have?

\begin{tabular}{|c|l|}
\hline NO & $\begin{array}{c}\text { WHAT DO ACADEMIC EDUCATORS } \\
\text { AND STUDENTS HAVE? }\end{array}$ \\
\hline 1 & Have different interests and talents \\
\hline 2 & Mostly have laptop and mobile phone \\
\hline 3 & $\begin{array}{l}\text { Mostly love to learn and improve their } \\
\text { knowledge }\end{array}$ \\
\hline 4 & Several Facilities and Financial Support \\
\hline
\end{tabular}

\subsection{System Design}

\subsubsection{Determine Scope and Objectives}

Before design a learning system based on digital technology utilization, first determine the scope and objectives to be achieved:

1. Where will this learning system be used? (in a classroom)

2. What are the goals? (search information and supported innovation)

3. What is the Subject?

4. What is the aim of this Subject?

5. What will be the main type of technology? (hardware or application)

6. Do we need supporting technology?

(supporting hardware or application)

7. What will be the form of learning? (fully academic, but students can learn

independently)

These scope and objectives will help us to create a better learning process.

\subsubsection{Prepare Digital Technology}

Our next step is to prepare the digital learning technology. This could be done by finding, buying, and using good technology products, or designing our own learning media, and if possible, constructing a learning module/device, or an interactive learning room.

\subsubsection{Relate Subject with Digital Technology}

We need this step for subjects that need special digital technology which have to be prepared separately from the learning room or university's facilities. What are the applications or hardware that suit best to teach the subject?

\subsubsection{Flexible Design Needs to be Considered}

With those various digital technologies we have prepared, including technology available in classroom, it is better to design a learning system using flexible tools and contents that can be use individually or integrated, in a proper way, as shown as examples in figure 2 and figure 3.

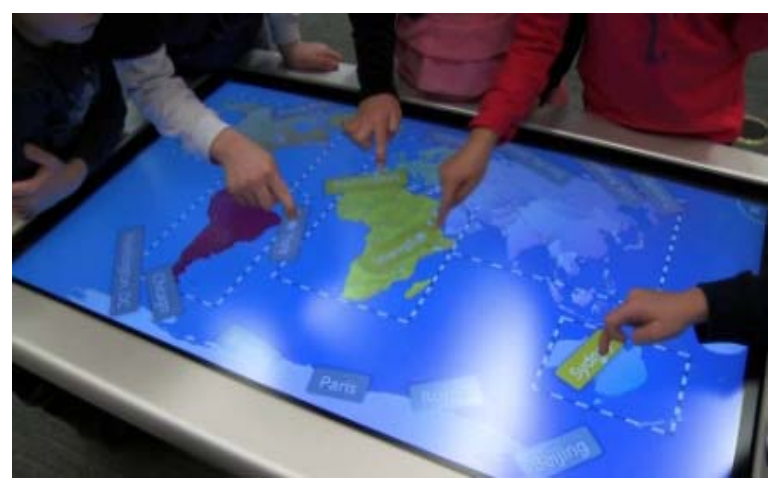

Figure 2. Learning with Interactive Technology (YouTube.com) 

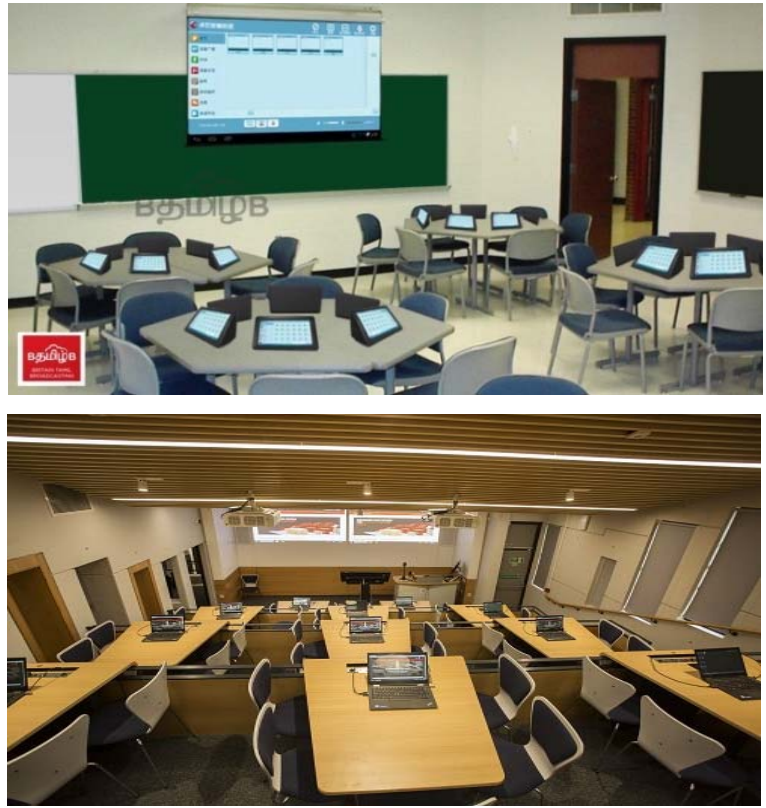

Figure 3. Flexible Design in Classroom (Schoms, 2017)

\subsection{Future Implementation}

From the learning system design concept, the output of research derives ideas and suggestions for future implementation in facing the development of digital technology and education future programs:

1. Hardware and Software Integration for supporting information and innovation

2. Digital technology needs to be utilized together in a positive way that meet the education goal, especially in educating people.

3. Website or Mobile Application that will accommodate all the roles and tasks of lecturers and students (interactive interface for learning activities)

4. Classified subjects with digital technology and their teaching method, to associate them with appropriate and universal interactive learning classroom

5. Build an academic zone for learning (learning center, mini digital study room, academic time zone, explore digital room, innovation room, information corner, and etc.)

\section{CONCLUSIONS}

A learning system design based on digital technology utilization can be built by determine scope and objectives, preparing digital technology, relating subject with digital technology, and designing the flexibility in learning. The results of this research offer a design of learning systems in classrooms that can use digital technology individually or integrated in a proper way, which will also support research activities and the good digital technology products assembled by our own nation and other nations.

It should be well designed and for information and innovation purposes. The security of those technology still has to be considered to maintain the dignity and sustainability of human civilization. This research needs further improvement but hopefully can bring benefit for academic educators in giving their best teaching digitally.

\section{ACKNOWLEDGMENT}

Thanks to my colleagues and students who have inspired and colored my teaching experience with their respects and reality problems in classroom.

\section{REFERENCES}

[1] Satzinger, et al., Systems Analysis \&Design in A Changing World, 5th ed.. USA: Course Technology, 2009.

[2] Jusak, Teknologi Komunikasi Data Modern. Yogyakarta: Penerbit ANDI, 2013.

[3] L. Rompis and R. Sualang, "Media Audio Video Sebagai Sarana Penunjang Proses Belajar-Mengajar",Seminar Nasional Ritektra VI di Unika De La Salle Manado, 2016.

[4] H. Sriwindono and F. Tumiwa, "Analisa Kesuksesan Learning Management System”,Seminar Nasional Ritektra VI di Unika De La Salle Manado, 2016. 
[5] E. Moelbatak andY. Bria,“Penerapan Model Multimedia sebagai Media Pembelajaran Alternatif untuk Meningkatkan Self Motivated Learning”,Seminar Nasional Ritektra VI di Unika De La Salle Manado, 2016.

[6] U.S., Winataputra, PEKERTI 1.04: Model-model Pembelajaran Inovatif. Pusat Antar Universitas untuk Peningkatan dan Pengembangan Aktivitas Instruksional Direktorat Jenderal Pendidikan Tinggi Departemen Pendidikan Nasional, 2005.

[7] U.S., Winataputra,PEKERTI 1.05: Pembe-lajaran Orang Dewasa. Pusat Antar Universitas untuk Peningkatan dan Pengembangan Aktivitas Instruksional Direktorat Jenderal Pendidikan Tinggi Departemen Pendidikan Nasional, 2005.

[8] D. Timbowo, "Manfaat Penggunaan Smartphone Sebagai Media Komunikasi”, in e-Journal Acta Diurna, V(2).

[9] Tribun Manado. (2014). BPS: Sulut Tertinggi dalam Penggunaan Internet di Indonesia. [Online]. Available: https://manado.tribunnews .com/2014/01/20/bps-sulawesi-utaratertinggi-dalam-penggunaan-internet-diindonesia

[10] Mangkei, P. (2017). Suara Manado: Jajaran program digital telkomsel untuk 2017. [Online]. Available: https://www.suaramanado.com/ berita /nasional/ilmu-pengetahuanteknologi/2017/06/ 11160/jajaranprogram-digital-telkomsel-untuk-2017

[11] Konfrontasi. (2016). Masyarakat manado pengguna data telkomsel meningkat. Diakses tanggal 14 Agustus 2017. Website:

https://www.konfrontasi.com/ content/ekbis/masyarakat-manadopengguna-data-telkomsel-meningkat 